\title{
Morphological and immunohistological changes in the skin in allogeneic bone marrow recipients
}

\author{
JP SLOANE, ${ }^{*}$ JA THOMAS, ${ }^{*}$ SF IMRIE, $\dagger$ DF EASTON, $\ddagger$ RL POWLES§
}

From the Department of Histopathology* and Leukaemia Unit, § Royal Marsden Hospital, and Divisions of Pathology $\dagger$ and Epidemiology, $\ddagger$ Institute of Cancer Research, Sutton, Surrey

SUMMARY Skin biopsies from leukaemic patients undergoing allogeneic bone marrow transplantations and treated prophylactically with cyclosporin A were analysed using histological, morphometric, and immunohistological techniques. Samples from donors were used to establish normal values. Biopsies taken from recipients two days before grafting were all histologically normal, but on immunohistological staining half of them showed a reduction in the number of epidermal Langerhans' cells and $29 \%$ a reduction in T inducer lymphocytes. Thirty two biopsies were taken from patients with rashes at various times after transplantation: 14 showed lichenoid changes consistent with graft versus host disease, three eczematous tissue reactions, two vesicular lesions, and 12 no histological abnormality. One sample showed changes intermediate between the lichenoid and eczematous forms. The numbers of epidermal Langerhans' cells were low during the first few weeks after transplantation and were normal or raised later regardless of histological appearances. Unlike epidermal Langerhans' cells, significant reductions in the numbers of lymphocytes were not seen. Lesions of all histological types contained mixtures of $\mathrm{T}$ inducer and $\mathrm{T}$ suppressor/cytotoxic cells, although the eczematous and vesicular lesions contained higher proportions of $\mathrm{T}$ inducer cells. Epidermal infiltrates invariably contained $\mathrm{T}$ suppressor/ cytotoxic cells but infiltration of epidermis by $T$ inducer cells occurred only in the presence of normal numbers of epidermal Langerhans' cells. Natural killer cells were not identified. The immunological appearances of the various histological subgroups thus change with time after transplantation.

Rashes are common after bone marrow transplantation, and biopsy of the skin is often performed. Most samples are taken for the assessment of graft versus host disease, which is encountered more often in the skin than in any other organ.

It is now generally accepted that cutaneous graft versus host disease occurs as a lichenoid dermatitis with a highly epidermotropic mononuclear cell infiltrate associated with epidermal basal cell vacuolation and necrosis. ${ }^{1}$ These changes are not, however, pathognomonic of graft versus host disease and may occur in other conditions. ${ }^{23}$ Furthermore, dermatitis after grafting may take other forms, the significance of which is not clear.

The purpose of this study was to define the histological appearances of the skin before and after bone marrow tansplantation for leukaemia and to characterise them further with a panel of monoclonal antibodies against immune cells using immunohistological and morphometric techniques. By comparing samples with those obtained from normal donors, we hoped to clarify some of the immunopathological changes taking place and to identify any features which might have diagnostic value.

\section{Material and methods}

Ellipses of skin $6-10 \mathrm{~mm}$ long were obtained from the posterior iliac crest of bone marrow donors under general anaesthesia at the time of marrow harvest. Informed consent was obtained. Biopsies of similar size were also obtained under general anaesthesia from the anterior chest wall of marrow recipients at the site of insertion of the Hickman catheter two days before transplantation. Punch biopsies ( 2 or $4 \mathrm{~mm}$ ) were taken from recipients with rashes at various times (8-436 days) after transplantation. Samples were taken from the site of the rash.

Recipients were between 2 and 42 years of age; 
Table 1 Immunological reagent panel

\begin{tabular}{|c|c|c|c|c|}
\hline Antibodies & $\begin{array}{l}\text { Abbreviation } \\
\text { in text }\end{array}$ & Specificity & Source & Reference \\
\hline $\begin{array}{l}\text { Monoclonal (mouse)* } \\
\text { T11 }\end{array}$ & $\mathrm{T} 11$ & $\begin{array}{l}\text { Sheep erythrocyte receptor on } \\
\text { peripheral } T \text { cells }\end{array}$ & \multirow{3}{*}{ Coulter Clone } & \multirow{3}{*}{4} \\
\hline $\mathrm{T} 4$ & $\mathrm{~T} 4$ & $\begin{array}{l}\mathrm{T} \text { inducer cells; } 60 \% \\
\text { peripheral T cells }\end{array}$ & & \\
\hline $\mathrm{T} 8$ & $\mathrm{~T} 8$ & $\begin{array}{l}\text { T suppressor/cytotoxic cells; } \\
35 \% \text { peripheral T cells }\end{array}$ & & \\
\hline $\mathrm{T} 10$ & OKT10 & Activated $\mathrm{T}$ cells & Orthomune & 5 \\
\hline Pan B & Pan B & $\begin{array}{l}\text { Peripheral B cells; unreactive } \\
\text { with plasma cells }\end{array}$ & Dakopatts & 6 \\
\hline 2DI & HLe-1 & $\begin{array}{l}\text { Human leukocyte antigen- } 1 \text { on } \\
\text { peripheral (B\&T) lymphocytes; } \\
\text { some monocytes; unreactive with } \\
\text { plasma cells }\end{array}$ & $\begin{array}{l}\text { Dr P Beverley, } \\
\text { London }\end{array}$ & 7 \\
\hline HNK-1 & HNK-1 & Human natural killer cells & Becton-Dickinson & 8 \\
\hline W6/32 & HLA-ABC & HLA-ABC antigens & Seralab & 9 \\
\hline 12 & HLA-DR & $\begin{array}{l}\text { HLA-DR antigens on B cells; } \\
\text { activated T cells; specialised } \\
\text { antigen presenting cells }\end{array}$ & Coulter Clone & 10 \\
\hline NA1/34 & HTA-1 & $\begin{array}{l}\text { Human thymocyte antigen-1 (HTA-1) } \\
\text { on cortical thymocytes and } \\
\text { epidermal Langerhans' cells }\end{array}$ & $\begin{array}{l}\text { Prof AJ McMichael, } \\
\text { Oxford }\end{array}$ & 11 \\
\hline $\begin{array}{l}\text { Polyclonal (rabbit or goat) } \\
\text { alkaline phosphatase conju } \\
\text { antisera to } \\
\text { Human immunoglobulins } \\
(\gamma, \alpha, \mu, \delta, \kappa, \lambda)\end{array}$ & & B cells and plasma cells & Sigma/Tago & \\
\hline
\end{tabular}

*All monoclonal antibodies were labelled with sheep antimouse IgG conjugated to alkaline phosphatase (Sigma; dilution $1 / 25)$ except for monoclonal antibody HNK-1, which was labelled with goat antimouse IgM conjugated to alkaline phosphatase (Miles-Yeda; dilution 1/30).

17 were male and 11 female. All patients received marrow from family member donors. In 17 , the marrow was matched on HLA typing and mixed lymphocyte reaction. The remaining 11 were matched at only one haplotype with a varying degree of HLA or mixed lymphocyte reaction incompatibility, or both. Pretransplant conditioning was achieved using cyclophosphamide (two doses, $60 \mathrm{mg} / \mathrm{kg}$ ) and total body irradiation $(9.5 \mathrm{~Gy}$ at $0.025 \mathrm{~Gy} / \mathrm{min}$ ). Three patients received melphalan $\left(85-110 \mathrm{mg} / \mathrm{m}^{2}\right)$ and total body irradiation and two received high dosage melphalan $\left(240 \mathrm{mg} / \mathrm{m}^{2}\right)$ without irradiation. The primary diagnosis was acute myeloid leukaemia in 24 patients, chronic granulocytic leukaemia in two patients, and acute lymphoblastic leukaemia in two patients. All patients received cyclosporin A prophylactically, generally at a dosage of $12.5 \mathrm{mg} / \mathrm{kg} /$ day starting one day before grafting.

The skin biopsies were divided in two; one half was subjected to routine formalin fixation and paraffin embedding and the other half was embedded in OCT compound on slices of cork and snap frozen in liquid nitrogen. Paraffin embedded sections were cut at $4 \mu \mathrm{m}$ and stained with haematoxylin and eosin. Frozen sections were cut at $5 \mu \mathrm{m}$ and labelled by direct and indirect immunoalkaline phosphatase techniques using the panel of reagents shown in Table 1.

Conventional histochemical staining for ATPase was carried out as described previously. $"$ i

Cells were counted within the epidermis and the most superficial $0.6 \mathrm{~mm}$ of the dermis (1 high power microscope field). Perivascular dermal cells were distinguished from those lying free within the dermis between the vessels and the epidermis. The length of the specimen was determined by making an accurate tracing of the epidermal surface on paper. This was achieved using a drawing attachment for a Leitz Orthoplan microscope which allows simultaneous visualisation of the section and the paper. The length of the tracing was determined using a Reichert-Jung MOP-Videoplan Image Analyser and divided by the magnification, calculated using a stage micrometer. Cell counts in each compartment of the skin were expressed as number per millimetre of epidermis.

\section{Results}

NORMAL DONORS

Skin samples from 12 normal donors were analysed; 
Table 2 Antibody labelled cells (per $\mathrm{mm}$ ) in 12 normal donors

\begin{tabular}{|c|c|c|c|c|c|}
\hline & $H T A-1^{+}$ & HLe-1 ${ }^{+}$ & $T 11^{+}$ & $T 8^{+}$ & $T 4^{+}$ \\
\hline $\begin{array}{l}\text { Epidermis } \\
\text { Absolute range } \\
\text { (mean) }\end{array}$ & $\begin{array}{l}13-28 \\
(22)\end{array}$ & $\begin{array}{l}0-3 \\
(0.8)\end{array}$ & $\begin{array}{l}0-4 \\
(0 \cdot 8)\end{array}$ & $\begin{array}{l}0-0.6 \\
(0.05)\end{array}$ & $\begin{array}{l}0-0.7 \\
(0.2)\end{array}$ \\
\hline $\begin{array}{l}\text { Free dermal cells } \\
\text { Absolute range } \\
\text { (mean) }\end{array}$ & $\begin{array}{l}0-9 \\
(3)\end{array}$ & $\begin{array}{l}0 \cdot 3-5 \\
(2)\end{array}$ & $\begin{array}{l}0-1 \\
(0 \cdot 4)\end{array}$ & $\begin{array}{l}0-1 \\
(0 \cdot 2)\end{array}$ & $\begin{array}{l}0-1 \\
(0 \cdot 2)\end{array}$ \\
\hline $\begin{array}{l}\text { Perivascular dermal cells } \\
\text { Absolute range } \\
\text { (mean) }\end{array}$ & $\begin{array}{l}2-22 \\
(11)\end{array}$ & $\begin{array}{l}24-107 \\
(56)\end{array}$ & $\begin{array}{l}7-42 \\
(21)\end{array}$ & $\begin{array}{l}0.9-21 \\
(7)\end{array}$ & $\begin{array}{l}10-42 \\
(22)\end{array}$ \\
\hline
\end{tabular}

the immunohistological results are summarised in Table 2. All specimens were normal on conventional histological examination. Absolute normal ranges were chosen as all values showed a skewed distribution with a peak at the left, with the exception of epidermal and perivascular HTA-1 ${ }^{+}$cells, which showed a more or less normal distribution.

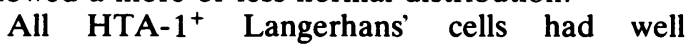
developed processes. Most were within the epidermis but moderate numbers were seen around the dermal blood vessels and a few were also present free within the upper dermis. Conventional histochemical stains for ATPase were also used to identify Langerhans' cells in two specimens. Epidermal counts were identical to those obtained immunohistologically, but the dermis contained some ATPase ${ }^{+}$ HTA- $1^{+}$dendritic cells. Epidermal Langerhans' cell counts were higher than we have previously reported in necropsy studies using these methods. ${ }^{11}$

Most of the $T$ lymphocytes were located in the perivascular compartment with only small numbers in the epidermis or free within the dermis. The ratio of $\mathrm{T}^{+}$to $\mathrm{T}^{+} \mathrm{T}$ cells in the perivascular compartment varied considerably from $2: 1$ to $16: 1$, but the $\mathrm{T} 4^{+\cdot} \mathrm{T}$ cells always exceeded $\mathrm{T} 8^{+}$.

The presence of B cells was not shown with antibodies to human immunoglobulins or the pan $\mathrm{B}$ cell marker. Neither $\mathrm{HNK}-1^{+}$nor $\mathrm{OKT} 10^{+}$cells were identified.

The number of HLe- $1^{+}$cells exceeded $\mathrm{T} 11^{+}$cells within the dermis owing to the presence of cells with the cytological features of macrophages. These were absent from the epidermis, where the $\mathrm{HLe}-1^{+}$and $\mathrm{T}_{11}{ }^{+}$cell numbers were roughly equal.

Some of the results with monoclonal antibody 12 directed against HLA-DR antigens were unexpected. Only a small proportion of epidermal Langerhans' cells were positive (range $0-3$, mean 0.9 per $\mathrm{mm}$ ) and the number of positive dermal cells varied considerably from 0 to 93 per mm (mean 46 per $\mathrm{mm}$ ). All positive dermal cells had the morphology of macrophages or dendritic cells. Weak patchy keratinocyte staining was seen in four subjects.

HLA-ABC staining was strong on keratinocytes, endothelial cells, and all dermal leucocytes. Weaker staining was seen in hair follicles, sebaceous glands, sweat glands, and nerves. Fibroblasts and smooth muscle cells were negative.

\section{BONE MARROW RECIPIENTS BEFORE}

TRANSPLANTATION

Samples from all 14 patients analysed were normal on conventional histological examination. The immunohistological findings are summarised in Table 3. Values were similar to those obtained for normal donors with the following exceptions.

Epidermal Langerhans' cell counts were below the lower limit of normal in seven patients. Perivascular $\mathrm{T}^{+}$cells were reduced $(3-8$ per $\mathrm{mm}$ ) in four cases, all with low epidermal Langerhans' cell counts. In two of these the $\mathrm{T}^{+}: \mathrm{T}^{+}$ratio was less than 1 .

There was an increase in HLe- $1^{+}$cells free within the dermis in four patients largely due to an increase

Table 3 Antibody labelled cells (per $\mathrm{mm}$ ) in 14 recipients two days before grafting

\begin{tabular}{|c|c|c|c|c|c|}
\hline & $H T A-1^{+}$ & HLe-1 ${ }^{+}$ & $\mathrm{T}_{11}+$ & $T 8^{+}$ & $\mathrm{T4}^{+}$ \\
\hline $\begin{array}{l}\text { Epidermis } \\
\text { Absolute range } \\
\text { (mean) } \\
\text { Free dermal cells }\end{array}$ & $\begin{array}{l}2-21 \\
(13)\end{array}$ & $\begin{array}{l}0-2 \\
(0 \cdot 3)\end{array}$ & $\begin{array}{l}0-2 \\
(0 \cdot 6)\end{array}$ & $\begin{array}{l}0-1 \\
(0 \cdot 1)\end{array}$ & $\begin{array}{l}0-1 \\
(0 \cdot 3)\end{array}$ \\
\hline $\begin{array}{l}\text { Absolute range } \\
\text { (mean) } \\
\text { Perivascular derma }\end{array}$ & $\begin{array}{l}0-8 \\
(2)\end{array}$ & $\begin{array}{l}0-8 \\
(4)\end{array}$ & $\begin{array}{l}0-2 \\
(0-5)\end{array}$ & $\begin{array}{l}0-2 \\
(0-3)\end{array}$ & $\begin{array}{l}0-2 \\
(0 \cdot 6)\end{array}$ \\
\hline $\begin{array}{l}\text { Absolute range } \\
\text { (mean) }\end{array}$ & $\begin{array}{l}4-21 \\
(9)\end{array}$ & $\begin{array}{l}18-71 \\
(41)\end{array}$ & $\begin{array}{l}13-55 \\
(23)\end{array}$ & $\begin{array}{l}0 \cdot 7-12 \\
(6)\end{array}$ & $\begin{array}{l}3-39 \\
(18)\end{array}$ \\
\hline
\end{tabular}




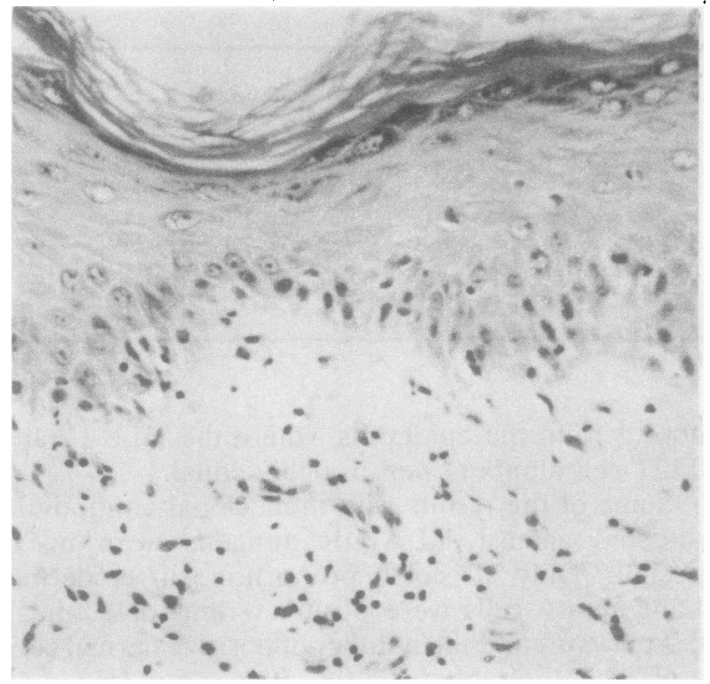

Fig. 1 Diffuse lichenoid lesion. The dermal mononuclear cells show no perivascular orientation and those within the epidermis are concentrated in the basal layer, which shows individual cell necrosis and vacuolation. Haematoxylin and eosin $\times 220$.

in melanophages. B cells and $\mathrm{HNK}-1^{+}$and $\mathrm{OKT} 10^{+}$ cells were not identified.

HLA-DR antigen staining was similar to that seen in normal controls, with few positive epidermal Langerhans' cells and a variable number of positive dermal leucocytes. Two patients showed weak, patchy keratinocyte staining. HLA-ABC antigen staining was identical to that seen in normal donors.

\section{BONE MARROW RECIPIENTS AFTER \\ TRANSPLANTATION}

Thirty two biopsies from 28 patients were analysed and fell into the following histological categories.

(a) Lichenoid lesions (graft versus host disease) Histological findings

This change was seen in 14 samples. It took the form

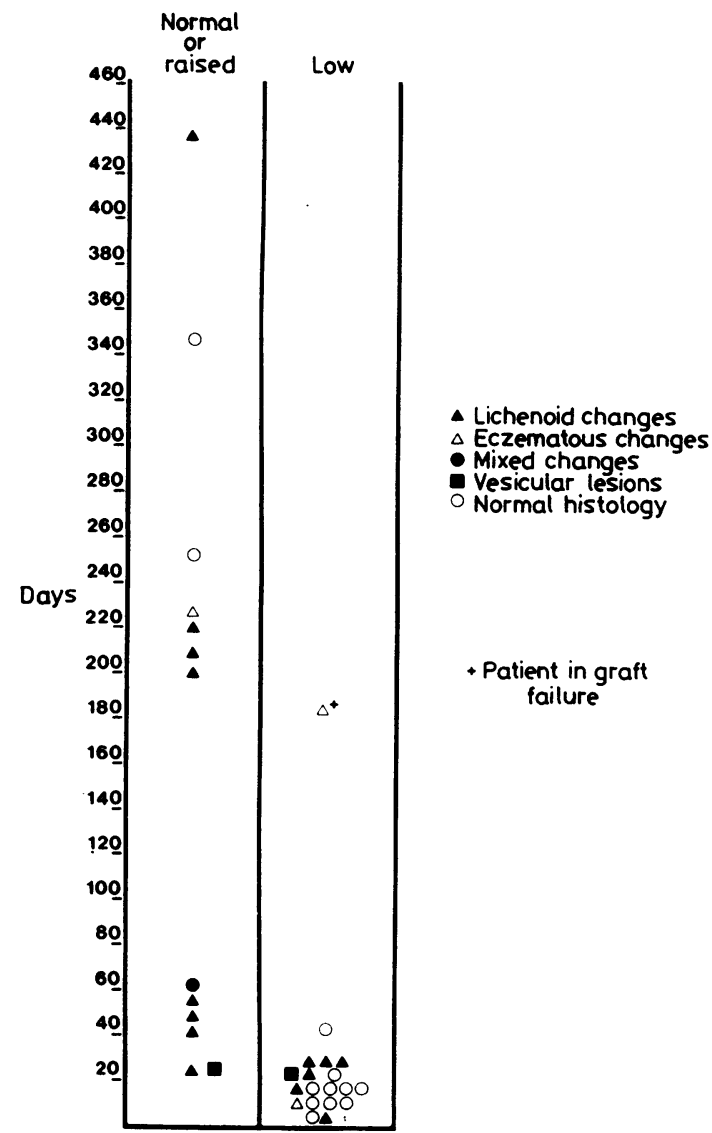

Fig. 2 Relation between epidermal Langerhans' cell count and time after transplantation. Biopsies with normal or high epidermal Langerhans' cell counts are in the left hand column and those with low counts are in the right. The time (in days) between transplantation and biopsy is indicated on the left.

of a band-like infiltrate of mononuclear cells in the papillary and upper reticular dermis, extending into the lower layers of the epidermis, which exhibited basal vacuolation and necrosis and a mild to moder-

Table 4 Antibody labelled cells (per mm length of skin) in lichenoid lesions

\begin{tabular}{|c|c|c|c|c|c|}
\hline & $H T A-I^{+}$ & HLe-1 ${ }^{+}$ & $T 11^{+}$ & $T 8^{+}$ & $\mathrm{T4}^{+}$ \\
\hline $\begin{array}{l}\text { Epidermis } \\
\text { Absolute range } \\
\text { (mean) } \\
\text { Free dermal cells }\end{array}$ & $\begin{array}{l}0-39 \\
(9)\end{array}$ & $\begin{array}{l}4-29 \\
(17)\end{array}$ & $\begin{array}{l}5-24 \\
(16)\end{array}$ & $\begin{array}{l}1-13 \\
(7)\end{array}$ & $\begin{array}{l}0-8 \\
(4)\end{array}$ \\
\hline $\begin{array}{l}\text { Absolute range } \\
\text { (mean) } \\
\text { Perivascular dermal cells }\end{array}$ & $\begin{array}{l}0-6 \\
(1)\end{array}$ & $\begin{array}{l}14-139 \\
(52)\end{array}$ & $\begin{array}{l}11-133 \\
(46)\end{array}$ & $\begin{array}{l}1-69 \\
(14)\end{array}$ & $\begin{array}{l}1-75 \\
(18)\end{array}$ \\
\hline $\begin{array}{l}\text { Absolute range } \\
\text { (mean) }\end{array}$ & $\begin{array}{l}0-17 \\
(4)\end{array}$ & $\begin{array}{l}25-158 \\
(62)\end{array}$ & $\begin{array}{l}13-152 \\
(57)\end{array}$ & $\begin{array}{l}2-105 \\
(33)\end{array}$ & $\begin{array}{l}4-65 \\
(38)\end{array}$ \\
\hline
\end{tabular}

HTA-1 ${ }^{+}$counts are derived from all 14 biopsies. Values for $\mathrm{HLe}-1^{+}, \mathrm{T}_{1} 1^{+}, \mathrm{T}^{+}$, and $\mathrm{T}^{+}$are derived only from the nine diffuse lesions. 


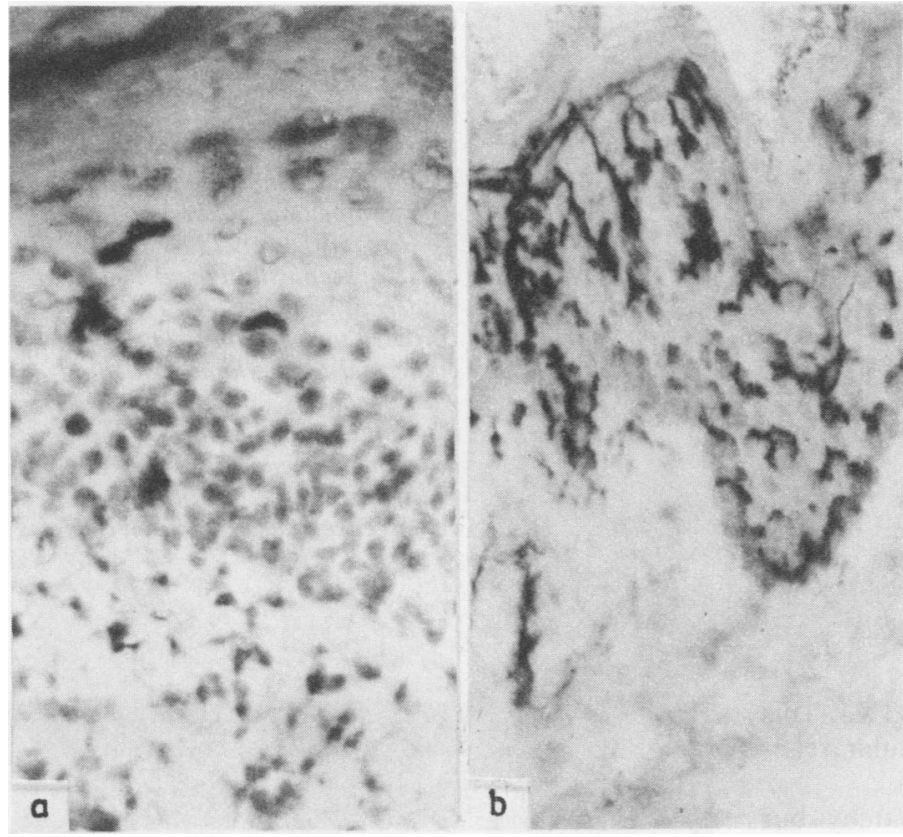

Fig. 3 Frozen sections of skin stained for epidermal Langerhans' cells with monoclonal antibody NA1/34 against HTA-1 antigen. (a) Biopsy with lichenoid changes taken 28 days after grafting showing considerable reduction in epidermal Langerhans' cells. The cells are degenerate with poorly formed processes. (b) Histologically normal sample taken 220 days after transplantation showing normal epidermal Langerhans' cell numbers. $\times$ 315.

ate degree of spongiosis (Fig. 1). In nine cases the changes were diffuse, affecting most or all of the specimen, whereas in five they occurred as small foci with zones of intervening normal skin. In two of the diffuse cases vacuolation and necrosis of basal cells were absent, the epidermis showing spongiosis only.

Hair follicles showed changes similar to those seen in the epidermis. The upper portions of sweat ducts often showed individual cell necrosis and mononuclear cell infiltration, but the lower portions and the sweat gland coils were usually spared.

\section{Immunohistological findings}

The immunohistological findings are summarised in Table 4. Numbers of epidermal Langerhans' cells were reduced in six samples (0-3 per $\mathrm{mm}$ ), normal in six (14-28 per $\mathrm{mm}$ ), and increased in two (36 and 39 per $\mathrm{mm}$ ). ATPase stains were performed on two samples with low epidermal Langerhans' cell numbers and two with normal values. Epidermal Langerhans' cell counts in these cases were the same as those obtained using monoclonal antibody NA1/ 34 identifying the HTA-1 antigen. Samples with low epidermal Langerhans' cell numbers were all taken between eight and 30 days after transplantation and those with normal or increased numbers between 21 and 436 days.

The relation between epidermal Langerhans' cell counts and time after transplantation for all posttransplant biopsies is shown in Fig. 2. There was a clear correlation between epidermal Langerhans' cell numbers and time after transplantation (Spearman rank correlation $(s=0.68, p<0.001))$ but no apparent relation with histological appearances (Fig. 3).

The degree of leucocyte infiltration varied considerably from section to section in focal lichenoid lesions. $\mathrm{HLe}-1^{+}, \mathrm{T}_{1} 1^{+}, \mathrm{T}^{+}$, and $\mathrm{T}^{+}$cells were therefore counted only in the nine diffuse cases.

In the epidermis, counts for HLe- $1^{+}, \mathrm{T}_{11}{ }^{+}$, and $\mathrm{T}^{+}$cells were increased in all nine biopsies, but $\mathrm{T}^{+}$ cells were increased only in the five cases in which the epidermal Langerhans' cell numbers were normal or increased (Fig. 4). The severity of the epidermal changes was not related to the numbers of epidermal Langerhans' cells or $\mathrm{T}^{+}$cells. In contrast, all cell types (including $\mathrm{T}^{+}$) were increased in the upper dermis away from the vessels in all nine samples. Cell counts in the perivascular compartment were very variable: of nine biopsies $\mathrm{HLe}-\mathrm{1}^{+}$ cells were increased in only one, $\mathrm{T}_{11^{+}}$and $\mathrm{T} 8^{+}$cells in six, and $\mathrm{T}^{+}$cells in five. Perivascular $\mathrm{T}^{+}$cells were actually reduced in two biopsies, both with low numbers of epidermal Langerhans' cells.

The mean $\mathrm{T}^{+}: \mathrm{T} 8^{+}$ratio for free and perivascular dermal cells was 1.9:1 but varied considerably from $0 \cdot 15-4 \cdot 25: 1$. The mean value was significantly lower than in the eczematous and vesicular reactions (Wilcoxon's rank sum test, $p=0.002$ ).

The proportion of $\mathrm{T} 11^{+}$cells in the perivascular 


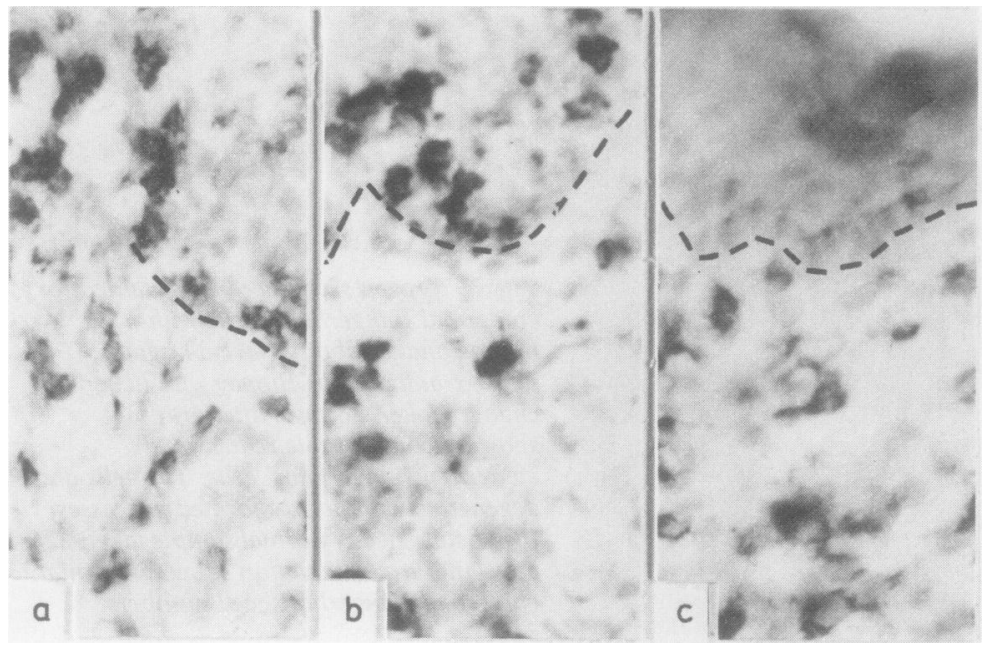

Fig. 4 Frozen sections of a biopsy exhibiting lichenoid changes stained with monoclonal antibodies T11 (a), $\mathrm{T8}(\mathrm{b})$, and $\mathrm{T4}$ (c). $\mathrm{TI1}^{+}$and $\mathrm{Tr}^{+} \mathrm{T}$ cells are seen within the dermis and epidermis whereas $\mathrm{T4}^{+} \mathrm{T}$ cells are confined to the dermis. The epidermal Langerhans' cell count was low in this sample. The broken lines indicate the dermo-epidermal junction. The end of the broken line in (a) marks a cleft formed by coalescence of necrotic basal cells. $\times$ 315.

region varied from $28 \%$ to $51 \%$ (mean $43 \%$ ). This was lower than in eczematous and vesicular reactions (see below).

HLA-DR antigen staining showed patchy but strong staining of keratinocytes in all lesions, but nearly all epidermal Langerhans' cells were negative. Large numbers of infiltrating mononuclear cells were positive; many were macrophages or dendritic cells but some also showed lymphocyte morphology. That at least some of the lymphocytes were HLA$\mathrm{DR}^{+}$was supported by the considerable excess of the sum of $\mathrm{T} 11^{+}$and HLA-DR ${ }^{+}$cells over those staining for the HLe-1 antigen. Staining for HLA$A B C$ antigens was similar to that seen in normal skin.

No B lymphocytes or $\mathrm{HNK}^{+}$or OKT $10^{+}$cells were seen, and no evidence of immunoglobulin deposition was found.

\section{(b) "Eczematous" changes}

Histological findings

In three patients the skin showed changes more in keeping with an eczematous tissue reaction (Fig. 5). The dermal mononuclear cell infiltrate was heavily concentrated around blood vessels and showed less epidermotropism; those cells which infiltrated the epidermis were not confined to the lower layers and there was no blurring of the dermo-epidermal junction as seen in the lichenoid lesions. The epidermis showed spongiosis, acanthosis, and, in later specimens, parakeratosis. Basal layer damage was lacking. There was pronounced perivascular oedema in the upper dermis.

\section{Immunohistological findings}

The immunohistological findings are summarised in

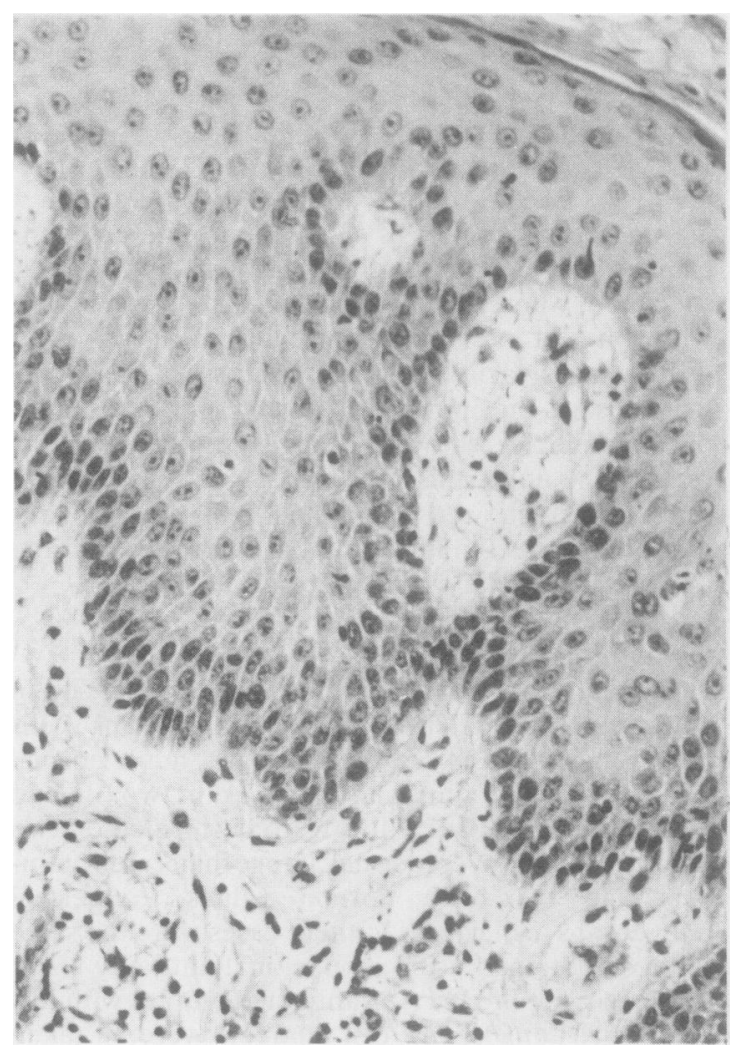

Fig. 5 Eczematous lesion. The dermal mononuclear cells are concentrated about blood vessels (bottom). Those in the epidermis are sparse and not focused on the lower layers.

The epidermis shows spongiosis, acanthosis, and parakeratosis (top right) but no basal damage. Haematoxylin and eosin $\times 220$. 
Table 5 Antibody labelled cells (per mm length of skin) in three eczematous lesions

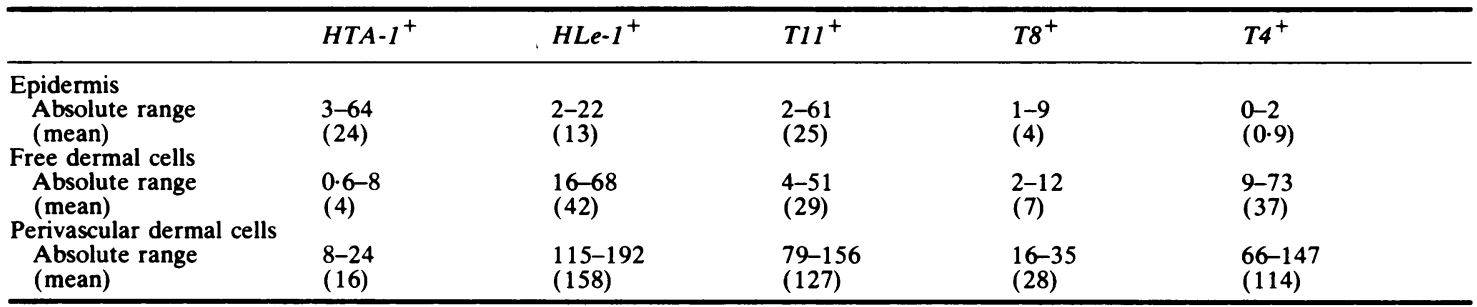

Table 5. Epidermal Langerhans' cell numbers were reduced in two biopsies (taken 12 and 188 days after transplantation) and increased in one (taken 220 days after transplantation). The sample with a low epidermal Langerhans' cell count taken at 188 days was from a patient in graft failure.

In the epidermis, $\mathrm{HLe}-1^{+}$and $\mathrm{T}_{11} 1^{+}$cells were increased in two of three samples and $\mathrm{T}^{+}$cells were increased in all three. $\mathrm{T}^{+}$cells, however, were only increased in the specimen with an increased number of epidermal Langerhans cells. As with lichenoid lesions, the severity of the epidermal changes was not related to the numbers of epidermal Langerhan's' cells or $\mathrm{T}^{+}{ }^{+}$cells. All cell types were increased in the upper dermis away from the vessels in all three cases. In the perivascular region, HLe$1^{+}, \mathrm{T} 11^{+}$, and $\mathrm{T} 4^{+}$cells were increased in all three cases and $\mathrm{T}^{+}$cells increased in two of three.

The mean $\mathrm{T}^{+}: \mathrm{T} 8^{+}$ratio for all dermal cells was $4 \cdot 3: 1$, with a range of $4 \cdot 2-4 \cdot 5: 1$. This was higher than that obtained for lichenoid lesions (see above). Between $62 \%$ and $84 \%$ (mean $73 \%$ ) of the $\mathrm{T} 11^{+}$ cells were located in the perivascular compartment. This compares with a mean of $43 \%$ for the lichenoid lesions. The difference is not surprising, however, as the lesions are defined partly by lymphocyte distribution.

No HLA-DR antigen staining of keratinocytes was seen, in contrast to the lichenoid lesions. Nearly all epidermal Langerhans' cells were negative. Large numbers of infiltrating leucocytes were HLA-DR ${ }^{+}$, however, and many of these showed lymphocyte morphology. The distribution of HLA-ABC antigen staining was similar to that seen in normal skin.

No B lymphocytes or $\mathrm{HNK}^{+}$or $\mathrm{OKT}^{+} 0^{+}$cells were seen, and there was no evidence of immunoglobulin deposition.

\section{(c) Mixed changes}

Histological findings

Mixed lichenoid and eczematous changes were seen in one sample taken 62 days after transplantation. In some areas the changes were of one or other type (Figs. 6 and 7), whereas other zones showed intermediate appearances.

\section{Immunohistological findings}

Epidermal Langerhans' cells were normal, at 21 per $\mathrm{mm}$. HLe- $1^{+}, \mathrm{T} 11^{+}, \mathrm{T}^{+}$, and $\mathrm{T}_{4}{ }^{+}$cells were increased in all three compartments. The $\mathrm{T}^{+}: \mathrm{T}^{+}$

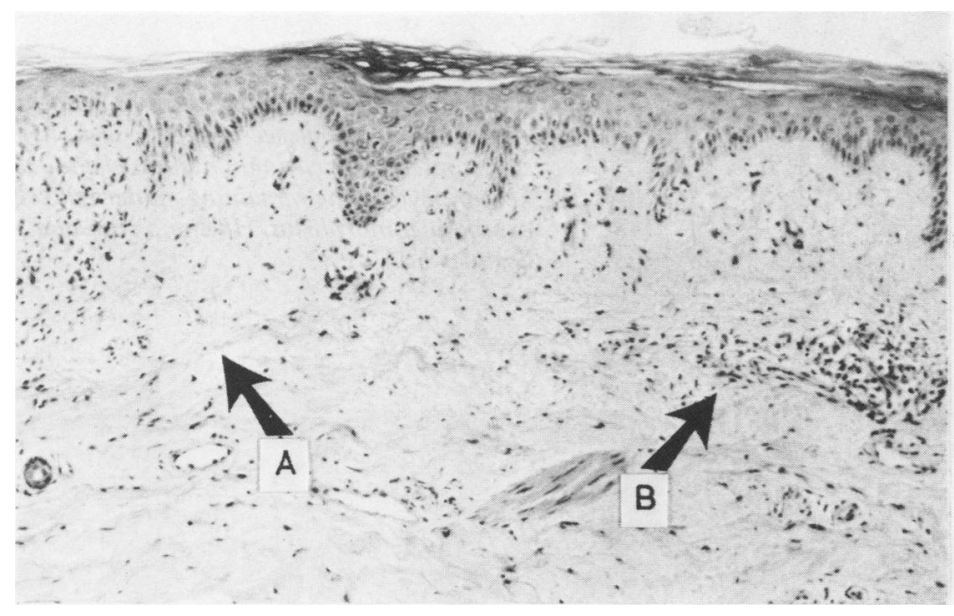

Fig. 6 Skin biopsy exhibiting mixed lichenoid $(A)$ and eczematous $(B)$ reactions. Haematoxylin and eosin $\times$ 88 . 


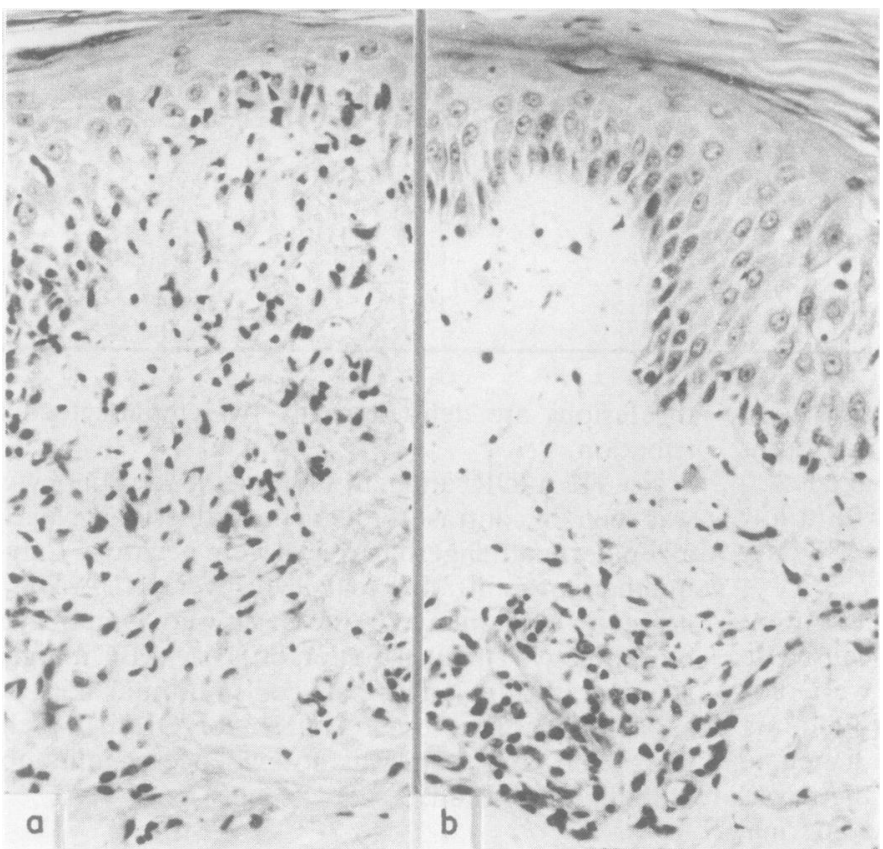

Fig. 7 Higher power of area (a) in Fig. 3 showing lichenoid appearance. (b) Higher power of area (b) showing eczematous reaction. Haematoxylin and eosin $\times 220$.

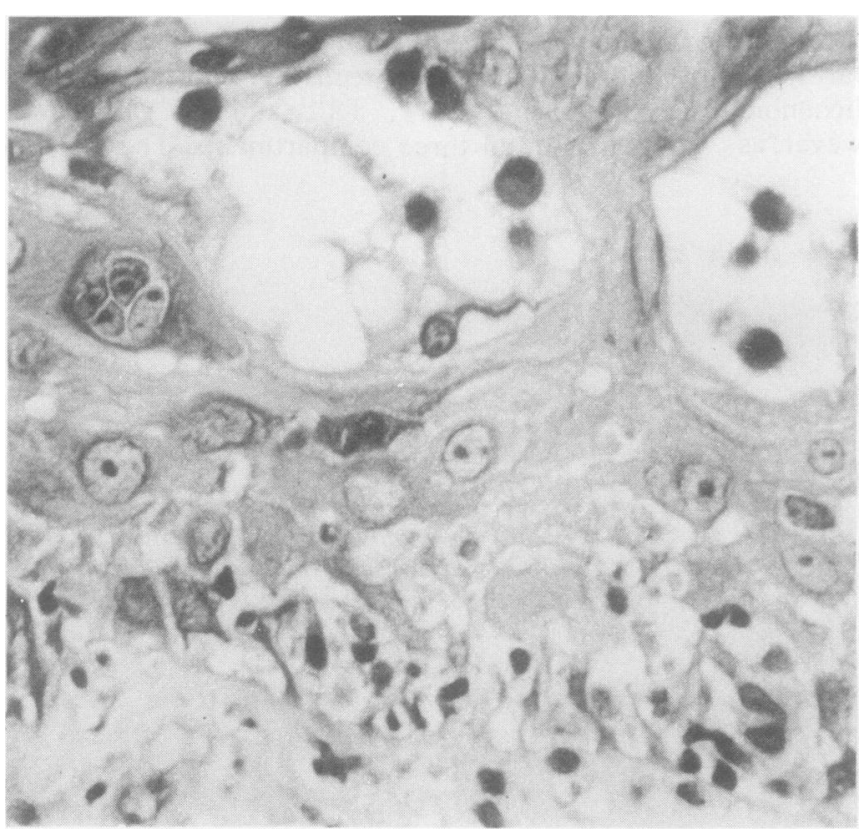

Fig. 8 Vesicular lesion. Two intraepidermal vesicles (which coalesce in deeper sections) surrounded by occasional multinucleate keratinocytes. The remaining epidermal cells exhibit pleomorphism. Haematoxylin and eosin $\times 504$. 
ratio for all dermal cells was $1 \cdot 6: 1$. Thirty seven per cent of $\mathrm{T}_{1} 1^{+}$cells were located in the perivascular compartment.

Keratinocytes showed strong focal positivity for HLA-DR antigens, but most epidermal Langerhans' cells were negative. Many infiltrating leucocytes were HLA-DR ${ }^{+}$and some showed lymphocyte morphology. The distribution of HLA-ABC staining was similar to that seen in normal skin.

No B lymphocytes or $\mathrm{HNK}^{+}$or $\mathrm{OKT}^{+} 0^{+}$cells were seen and there was no evidence of immunoglobulin deposition.

\section{(d) Vesicular lesions}

\section{Histological findings}

In two patients there were intraepidermal vesicles, around which occasional multinucleate epidermal cells were seen (Fig. 8). The mononuclear cell infiltrate showed a perivascular distribution with some exocytosis. Occasional individually necrotic epidermal cells were seen, but these were not confined to the basal region. The changes were reminiscent of a viral exanthema.

\section{Immunohistological findings}

Immunohistological stains for herpes simplex virus (types I and II) were negative.

Epidermal Langerhans' cell numbers were reduced in one sample (taken at 16 days) and normal in the other (taken at 21 days).

HLe $-1^{+}, \mathrm{T} 11^{+}, \mathrm{T} 8^{+}$, and $\mathrm{T} 4^{+}$cells could not be counted in the epidermis and upper dermis of one biopsy owing to technical problems. In the other specimen all cell types were increased in both compartments with the exception of $\mathrm{T}^{+}$cells in the upper dermis, which were within the normal range. Both specimens showed increased numbers of HLe $-1^{+}, \mathrm{T} 11^{+}$, and $\mathrm{T} 4^{+}$cells in the perivascular compartment, but $\mathrm{T}^{+}$cells were not increased.

There was no staining of keratinocytes for HLA-DR antigens and nearly all epidermal Langerhans' cells were negative. Many infiltrating leucocytes were HLA-DR ${ }^{+}$and some showed lymphocyte morphology.
HLA-ABC antigen staining was identical to that seen in the normal skin.

No B lymphocytes or $\mathrm{HNK}^{+}$or $\mathrm{OKT} 10^{+}$cells were seen and there was no evidence of immunoglobulin deposition.

\section{(e) Normal}

Twelve specimens showed no appreciable histological abnormality.

\section{Immunohistological findings}

The immunohistological findings are summarised in Table 6. Epidermal Langerhans' cell numbers were reduced in 10 biopsies (taken 5-42 days after transplantation) and normal in two (taken at 250 and 345 days).

Numbers of perivascular $\mathrm{T}$ lymphocytes $\left(\mathrm{T}_{11}{ }^{+}\right.$, $\mathrm{T}^{+}$, and $\mathrm{T}^{+}$) were reduced in two biopsies taken nine and 21 days after grafting. An increased number of perivascular $\mathrm{T}_{11}{ }^{+}$cells (with normal $\mathrm{T}^{+}$ and $\mathrm{T}^{+}$values) were found in one sample taken at 14 days. This patient subsequently developed cutaneous lichenoid graft versus host disease. Perivascular $\mathrm{T}^{+}$cells were increased in two samples taken at 12 and 42 days, although $\mathrm{T}_{11^{+}}$and $\mathrm{T}^{+}$ values were normal. One of these patients later developed lichenoid graft versus host disease and the other minor eczematous changes.

No staining of keratinocytes was seen on staining for HLA-DR antigens and most epidermal Langerhans' cells were negative. Some HLA-DR ${ }^{+}$ dermal cells were identified but all were macrophages/dendritic cells.

HLA-ABC antigen staining was identical to that seen in normal skin.

No B lymphocytes or $\mathrm{HNK}^{+}$or $\mathrm{OKT} 10^{+}$cells were seen and there was no deposition of immunoglobulin.

\section{Histological findings in patients with multiple biopsies}

More than one biopsy was taken from 17 patients but not all were available for immunohistological staining. All additional samples were taken on sepa-

Table 6 Antibody labelled cells (per mm length of skin) in 12 histologically normal samples taken after grafting

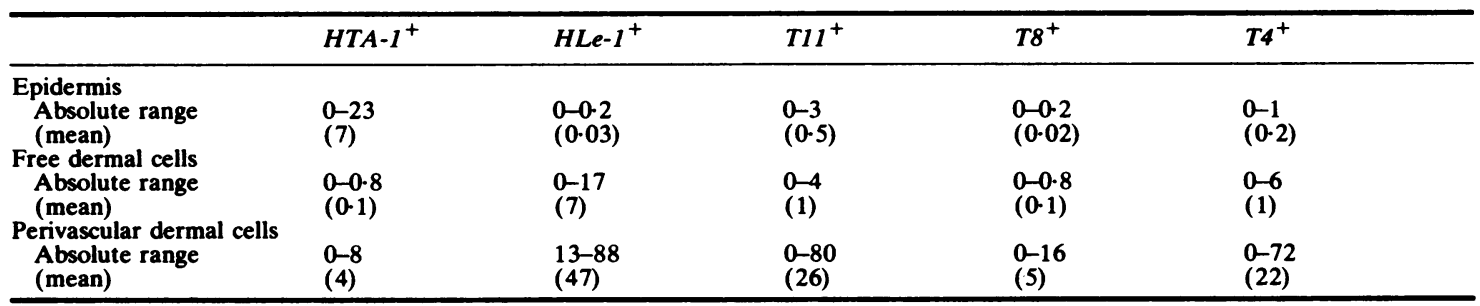


rate occasions and the maximum number per patient was four. In each case the additional samples showed lesions of the same type or appeared normal. This included the patient with mixed changes, in whom the skin showed mixed lichenoid and eczematous reactions in three samples but appeared normal in the fourth.

\section{Discussion}

The histological aspect of this study draws attention to the variety of appearances which may be encountered in skin biopsies taken from patients with rashes after allogeneic bone marrow transplantation. Lichenoid, eczematous, and vesicular tissue reactions were seen as well as a surprisingly high number of histologically normal samples.

There is strong clinical and experimental evidence for regarding the lichenoid lesions as cutaneous graft versus host disease. ${ }^{12}$ But appearances are not pathognomonic. In addition to lichen planus and related conditions of unknown aetiology, lichenoid changes may also occur as a reaction to a variety of drugs, ${ }^{13}$ including cytotoxic agents, ${ }^{14}$ and may even occur in association with disseminated carcinoma ${ }^{15}$ and malignant lymphoma (Sloane JP, et al; unpublished observations).

The histological appearances described as graft versus host disease in other studies usually coincide with those of our seven cases showing diffuse lichenoid changes with basal vacuolation and necrosis. It seems most unlikely, however, that the focal lesions and those without appreciable basal damage represent anything other than variations of the same basic tissue reaction. Lesions may be modified by immunosuppressive treatment and may even show a tendency to natural regression.

The significance of the eczematous reactions is much more difficult to ascertain. In another study we found that the infiltrating mononuclear cells are of donor origin in both the lichenoid and ezcematous reactions. ${ }^{16}$ Both types of lesion may occur at any time after transplantation and may be present in biopsies repeated over long periods. The occurrence and histological severity of both reactions is unrelated to epidermal Langerhans' cell or epidermal $\mathrm{T}^{+}$cell numbers (see below). Both contain mixtures of $\mathrm{T}^{+}$and $\mathrm{T}^{+} \mathrm{T}$ cells, although the eczematous lesions have a higher T4:T8 ratio. The one case in the present study with intermediate histological appearances may represent the superimposition of two pathological processes or form an important link between the two types of reaction. Although eczematous tissue reactions in transplanted patients may have the same pathogenesis as in non- transplanted subjects, the possibility that they represent some form of graft versus host reaction cannot be excluded. Further studies are underway to examine the clinical associations of lichenoid and eczematous reactions, particularly their association with hepatic and intestinal abnormalities.

Although the appearance of the vesicular lesions suggests infection by virus (a not uncommon complication of bone marrow transplantation), inclusions could not be shown. Immunohistological staining for herpes simplex virus was negative. Unfortunately, no tissue was available for electron microscopy.

The most important immunohistological changes were those in the epidermal Langerhans' cells. Their disappearance after transplantation regardless of histological appearance reflects their sensitivity to irradiation $^{17}$ and probably cytotoxic drugs. Antileukaemic chemotherapy is probably responsible for the less dramatic reductions before grafting, but replacement of bone marrow by leukaemic cells may also be a factor as epidermal Langerhans' cells are derived from marrow. ${ }^{18}$ The lack of staining for ATPase as well as HTA-1 antigen makes it more likely that there is an actual loss of cells rather than merely a change in marker characteristics.

In a previous study, using a monoclonal antibody to specific HLA-ABC antigens in transplanted patients matched for one haplotype, we showed that lymphocytes and macrophages in the skin are of donor origin in lichenoid and eczematous tissue reactions as well as in histologically normal biopsies. But we were unable to establish the origin of epidermal Langerhans' cells. ${ }^{16}$ Further studies using antibodies to HLA-DR specificities in patients matched for one haplotype should establish their identity. It is likely that the repopulating epidermal Langerhans' cells are of donor origin. Suitters and Lampert $^{19}$ have shown that epidermal Langerhans' cells are sensitive to the effects of graft yersus host disease, and yet epidermal Langerhans' cells in the present study were normal in numbers and morphology in graft versus host disease occurring later after transplantation. Furthermore, Katz et al $^{18}$ have shown that donor Langerhans' cells can repopulate the epidermis in experimental radiation chimeras. The time course of repopulation (beginning at about three weeks in our study) would also be consistent with donor origin; Lawler et $a^{20}$ have shown that dividing donor cells are first identified within the marrow about two weeks after transplantation.

Unlike epidermal Langerhans' cells, skin lymphocytes did not show a consistent reduction in numbers. Either cutaneous lymphocytes were not eliminated by the conditioning treatment or repopulation occurred quickly. We have identified donor lympho- 
cytes in the perivascular compartment in histologically normal skin two weeks after transplantation, ${ }^{16}$ which supports the latter interpretation.

The lymphocytes in all lesions were mixtures of $\mathrm{T}^{+}$and $\mathrm{T}^{+}$cells. It is of interest that $\mathrm{T}^{+}$cells were increased in the epidermis only when the epidermal Langerhans' cell count was above the lower limit of normal. We could not establish whether there were contacts between the epidermal Langerhans' cells and the epidermal $\mathrm{T} 4^{+} \mathrm{T}$ cells as double staining techniques were not used in this study. In one of the lichenoid lesions, however, the epidermal Langerhans' cells were unevenly distributed in the specimen and $\mathrm{T}^{+}$cell infiltration was concentrated in the areas of highest epidermal Langerhans' cell density. There was no relation between the intensity of the epidermal changes and the presence of epidermal $\mathrm{T}^{+}$cells in lesions of any type. Thus it appears that neither epidermal Langerhans' cells nor intraepidermal $\mathrm{T} 4^{+}$cells play an important role in the pathogenesis of either the lichenoid or eczematous reactions after marrow transplantation.

Although the mean $\mathrm{T}^{+}: \mathrm{T}^{+}$ratio for dermal cells was significantly higher in eczematous and vesicular lesions than in those with lichenoid histology, the relative proportions of the two cell types varied considerably from sample to sample in each histological group. The reasons for this variation are not known. Different modes of treatment, particularly with immunosuppressive drugs, may be important, as may the stage in the evolution of the lesion. Bhan $e t a l^{21}$ have provided some evidence that the relative proportions of $T$ cell subsets may change during the course of the lesions of lichen planus. Unlike the epidermis, the proportion of dermal $\mathrm{T}^{+}{ }^{+} \mathrm{T}$ cells in our study could not be related to Langerhans' cell numbers within either the epidermis or the dermis.

The presence of substantial numbers of $\mathrm{T}^{+}{ }^{+} \mathrm{T}$ cells in cutaneous graft versus host disease is at variance with the findings of a previous study by Lampert $e t a l,{ }^{22}$ who found that nearly all infiltrating cells were of the $\mathrm{T}^{+}$type. These workers also found that epidermal Langerhans' cells were reduced even in samples taken a long time after grafting. The explanation for these discrepancies is not clear. Although variations in the sensitivity of immunohistological techniques may play a part, differences in treatment, particularly the use of prophylactic cyclosporin A in our patients, may prove to be very important.

Some of the findings with monoclonal antibody $\mathrm{I} 2$ against HLA-DR antigens were unexpected. Few epidermal Langerhans' cells were seen, dermal leucocyte staining was variable, and keratinocytes were positive in a few normal individuals. HLA-DR antigens are complex and different staining patterns with different monoclonal antibodies to monomorphic determinants may be obtained. ${ }^{23}$ We were able, however, to confirm the findings of others that keratinocytes show HLA-DR positivity in graft versus host disease. ${ }^{2425}$ This occurred in lichenoid lesions with low or absent epidermal Langerhans' cells, which supports the contention that HLA-DR is produced by the keratinocytes themselves rather than derived from epidermal.Langerhans' cells. The lack of HLA-DR expression on the keratinocytes in the eczematous reaction is not understood and is under further investigation. The finding that at least some $\mathrm{T}$ lymphocytes are HLA-DR ${ }^{+}$indicates their activation, but further double labelling studies are necessary to determine precisely which subsets are positive.

Although $\mathrm{HNK}-1^{+}$cells have been identified in the peripheral blood after marrow transplantation, ${ }^{26}{ }^{27}$ we agree with others ${ }^{26}$ that these cells are not found in appreciable numbers in posttransplantation skin lesions.

We are indebted to the nursing and medical staff of the Leukaemia Unit and to the technical staff of the Department of Histopathology, Royal Marsden Hospital, Sutton. We thank Dr KV Sanderson for his helpful discussion and Valerie Power for her help in preparing the manuscript.

JAT is supported by Leukaemia Research Fund, grant no $81 / 16$.

\section{References}

' Lerner KG, Kao GF, Storb R, Buckner CD, Clift RA, Thomas ED. Histopathology of Graft-vs.-Host Reaction (GvHR) in human recipients of marrow from HL-A-matched sibling donors. Transplant Proc 1974;6:367-71.

${ }^{2}$ Pinkus H. Lichenoid tissue reactions. A speculative review of the clinical spectrum of epidermal basal cell damage with special reference to erythema dyschromicum perstans. Arch Dermatol $1973 ; 107: 840-6$.

${ }^{3}$ Weedon D. The lichenoid tissue reaction. Int J Dermatol 1982;21:203-6.

4 Reinherz EL, Schlossman SF. The characterization and function of human immunoregulatory $\mathrm{T}$ lymphocyte subsets. Immunology Today 1981;2:69-75.

${ }^{5}$ Hercend T, Ritz J, Schlossman SF, Reinherz EL. Comparative expression of T9, T10 and Ia antigens on activated human $\mathrm{T}$ cell subsets. Hum Immunol 1981;3:247-59.

- Stein H, Gerdes J, Mason DY. The normal and malignant germinal centre. Clin Haematol 1982;11:531-59.

' Pizzolo G, Sloane J, Beverley P, et al. Differential diagnosis of malignant lymphoma and nonlymphoid tumors using monoclonal antileukocyte antibody. Cancer 1980;46:2640-7.

${ }^{8}$ Abo T, Balch CM. A differentiation antigen of human NK and $\mathrm{K}$ cells identified by a monoclonal antibody (HNK-1).J Immunol 1981;127: 1024-9.

' Brodsky FM, Parham P, Barnstable CJ, Crumpton MJ, Bodmer WF. Monoclonal antibodies for analysis of the HLA system. Immunol Rev 1979;47:3-61. 
${ }^{10}$ Nadler LM, Stashenko P, Handy R, Pesando JM, Yunis EJ, Schlossman SF. Monoclonal antibodies defining serologically distinct HLA-D/DR related Ia-like antigens in man. Hum Immunol 1981;1:77-90.

" Thomas JA, Biggerstaff M, Sloane JP, Easton DF. Immunological and histochemical analysis of regional variations of epidermal Langerhans cells in normal human skin. Histochem $J$ 1984;16:507-19.

${ }^{12}$ Woodruff JM, Eltringham JR, Casey HW. Early secondary disease in the rhesus monkey: I. A comparative histopathologic study. Lab Invest 1969;20:499-511.

${ }^{13}$ Cochran RET, Thompson J, Fleming K, McQueen A. The psoriasiform eruption induced by practolol. J Cutan Pathol 1975;2:314-9.

${ }^{14}$ Sale GE, Lemer KG, Barker EA, Shulman HM, Thomas ED. The skin biopsy in the diagnosis of acute graft-versus-host disease in man. Am J Pathol 1977;89:621-33.

is Holmes RC, Cooper CB, Black MM, Jurecka W, McGibbon DH. Syndrome resembling graft-versus-host disease in a patient with disseminated carcinoma. $J \boldsymbol{R}$ Soc Med 1983;76:703-5.

${ }^{16}$ Thomas JA, Wakeling WF, Imrie SF, Sloane JP, Powles R, Lawler S. Chimerism in skin lesions of bone marrow transplant recipients. Transplantation (in press).

17 Fan J, Schoenfeld RJ, Hunter R. A study of epidermal clear cells with special reference to their relationship to the cells of Langerhans. J Invest Dermatol 1959;32:445-9.

${ }^{18}$ Katz SI, Tamaki K, Sachs DH. Epidermal Langerhans cells are derived from cells originating in bone marrow. Nature 1979; 282:324-6.

${ }^{14}$ Suitters AJ, Lampert IA. The loss of $\mathrm{Ia}^{+}$Langerhans' cells during graft-versus-host disease in rats. Transplantation 1983;36:540-6.
${ }^{20}$ Lawler SD, Baker MC, Harris H, Morgenstern GR. Cytogenetic studies on recipients of allogeneic bone marrow using the sex chromosomes as markers of cellular origin. $\mathrm{Br} \mathrm{J} \mathrm{Haematol}$ 1984;56:431-43.

21 Bhan AK, Harrist TJ, Murphy GF, Mihm MC. T cell subsets and Langerhans cells in lichen planus: in situ characterization using monoclonal antibodies. Br J Dermatol 1981;105:617-22.

${ }^{22}$ Lampert IA, Janossy G, Suitters A, et al. Immunological analysis of the skin in graft versus host disease. Clin Exp Immunol 1982; 50: 123-31.

${ }^{23}$ Gatter KC, Pulford KAF, Vanstapel MJ, et al. An immunohistological study of benign and malignant skin tumours: epithelial aspects. Histopathology 1984;8:209-27.

${ }^{24}$ Lampert IA, Suitters AJ, Chisholm PM. Expression of Ia antigen on epidermal keratinocytes in graft-versus-host disease Nature 1981;293:149-50.

${ }^{25}$ Mason DW, Dallman M, Barclay AN. Graft-versus-host disease induces expression of Ia antigen in rat epidermal cells and gut epithelium. Nature 1981;293:150-1.

${ }^{26}$ Favrot M, Janossy G, Tidman N, et al. $T$ cell regeneration after allogeneic bone marrow transplantation. Clin Exp Immunol 1983;54:59-72.

${ }^{27}$ Muller C, Schuch K, Pawelec G, Wilms K, Wernet P. Immunohistology of graft-versus-host disease mediated skin lesions and its correlation to a large granular lymphocyte surface phenotype and function. Blut 1982;44:89-94.

Requests for reprints to: Dr JP Sloane, Department of Histopathology, The Royal Marsden Hospital, The Haddow Laboratories, Clifton Avenue, Sutton, Surrey SM2 5PX, England. 